\title{
PENGARUH MODEL PEMBELAJARAN BERBASIS MASALAH TERHADAP HASIL BELAJAR SISWA PADA MATERI POKOKLISTRIK DINAMIS DI KELAS X SEMESTER II SMA NEGERI 14 MEDAN T.P. 2014/2015
}

\author{
Roniati Sinaga dan Sehat Simatupang \\ Jurusan Fisika FMIPA Universitas Negeri Medan \\ Jalan Willem Iskandar Pasar V Medan, Sumatera Utara \\ Roniati.sinaga@gmail.com
}

\begin{abstract}
ABSTRAK
Penelitian ini bertujuan untuk mengetahui pengaruh penggunaan model pembelajaran berbasis masalah untuk terhadap hasil belajar siswa pada materi listrik dinamis kelas X SMA Negeri 14 Medan T.P 2014/2015. Jenis penelitian ini adalah quasi eksperimen dengan populasi seluruh siswa kelas $\mathrm{X}$ SMA Negeri 14 Medan yang terdiri dari 9 kelas. Sampel penelitian diambil 2 kelas yang ditentukan dengan cluster random sampling, yaitu kelas X-3 sebagai kelas eksperimen dan kelas X-2 sebagai kelas kontrol. Instrumen yang digunakan untuk mengumpulkan data ada dua, yaitu: 1) Tes hasil belajar yang berbentuk pilihan ganda yang dibuat sebanyak 15 soal yang terdiri dari 5 pilihan yang telah dinyatakan valid oleh validator, dan 2) Lembar observasi aktivitas belajar siswa. Data penelitian menunjukkan rata-rata pretes kelas eksperimen adalah 35,74 dan pada kelas kontrol diperoleh rata-rata pretes 36,94. Setelah diberikan perlakuan pada masing-masing kelas diperoleh ratarata postes pada kelas eksperimen sebesar 74,07 dan pada kelas kontrol diperoleh rata-rata postes siswa 68,47. Hasil penelitian menggunakan uji t menunjukkan ada pengaruh yang signifikan penggunaan model pembelajaran berbasis masalah untuk terhadap hasil belajar siswa pada materi listrik dinamis kelas X.
\end{abstract}

Kata Kunci: pembelajaran berbasis masalah, hasil belajar.

\begin{abstract}
This study deals to determine the effect of the use of problem-based learning model for the learning outcomes of students in dynamic electrical material grade X Senior High School (SMA) 14 Medan a.y. 2014/2015. This research is a quasi experiment population of all class X Senior High School (SMA) 14 Medan, which consists of nine (9) classes. Samples were taken two classes are determined by cluster random sampling, the class X-3 as the experimental class and class of X-2 as the control class. There are two instruments that used to collect the data they are: 1) Test of the learning outcomes in the form of multiple choice consist of 15 questions and also 5 answer choices that have been declared valid by the validator, and 2) Observation sheet student learning activities. The research of data showed that the average class pre-test experiment was 35.74 and in the control class gained an average of 36, 94 .
\end{abstract}


After given the treatment to each class obtained an average grade post-test of the experiment class at 74.07 and in the control class gained an average of students' post-test 68.47. The results showed that there are the effect of the use of problem-based learning model for the student learning outcomes on the material dynamic electrical class $\mathrm{X}$.

Keywords: problem based learning, learning outcomes.

\section{PENDAHULUAN}

Pendidikan
Fisika sering dipandang merupakan kebutuhan sepanjang hayat, setiap manusia membutuhkan pendidikan sampai kapan dan dimana pun manusia berada karena pendidikan sangat penting, sebab tanpa pendidikan manusia akan sulit berkembang dan bahkan akan terbelakang. Pendidikan harus betulbetul diarahkan untuk menghasilkan manusia yang berkualitas dan mampu bersaing di samping memiliki budi pekerti yang luhur dan moral yang baik, karena pendidikan memegang peranan yang sangat penting dalam mempersiapkan manusia yang berkualitas bagi pembangunan negara. Keberhasilan membangun di sektor pendidikan mempunyai pengaruh yang sangat luas terhadap pembangunan di sektor lain.

Guru perlu memiliki pengetahuan tentang pendekatan dan teknik-teknik mengajar yang baik dan tepat sehingga kegiatan belajar yang efektif dan efisien dapat berlangsung sesuai tujuan yang diharapkan (Sagala, 2009).

Baik tidaknya kualitas guru dalam mengajar akan mempengaruhi keberhasilan belajar siswa. Guru harus mampu menciptakan suasana kelas yang kondusif bagi kelangsungan aktivitas belajar siswa. Salah satunya adalah menggunakan teknik pengajaran yang tepat terutama dalam pembelajaran fisika. sebagai suatu ilmu yang sulit oleh siswa dengan teori dan soal-soal yang sulit. Pernyataan ini diperoleh peneliti pada saat melakukan studi pendahuluan di SMA Negeri 14 Medan pada tanggal 14 Januari 2015 yaitu ada beberapa permasalahanpermasalahan yang ditemukan bahwa banyak siswa-siswi yang menganggap Fisika sebagai mata pelajaran yang menakutkan serta menganggap Fisika sebagai mata pelajaran yang sulit untuk dipelajari.

Berdasarkan hasil wawancara peneliti dengan salah satu guru fisika di SMA Negeri 14 Medan bahwa hasil ulangan harian Fisika belum memuaskan, nilai rata-rata siswa masih di bawah Kriteria Ketuntasan Minimal (KKM) yang sudah ditetapkan di sekolah yaitu 75 . Ketika diwawancarai lebih lanjut, ternyata setiap nilai siswa yang dilaporkan merupakan penilaian tugas pribadi, kehadiran siswa, dan kedisplinan siswa. Hal ini relevan dengan data yang diperoleh dari instrumen angket yang disebarkan kepada 40 siswa diperoleh bahwa $62,86 \%$ mengatakan fisika sulit dan kurang menarik, $28,57 \%$ siswa mengatakan fisika tidak terlalu sulit tapi kurang menarik, dan 8,57\% siswa mengatakan fisika menarik dan menyenangkan.

Rendahnya hasil belajar berdasarkan wawancara guru fisika tersebut, disebabkan oleh : (1) Model 
pembelajaran fisika yang kurang bervariasi (model konvensional) dimana proses belajar mengajar yang dilakukan terpusat pada guru (teacher centered) dengan urutan menjelaskan, memberi contoh, latihan dan penugasan. Variasi metode pembelajaran yang diberikan guru kurang disesuaikan berdasarkan karakteristik materi pelajaran yang diajarkan. (2) Alatalat laboratorium yang masih kurang lengkap. (3) Guru jarang menggunakan media pembelajaran. (4) Guru jarang memberi kesempatan kepada siswa untuk berinteraksi dengan teman sejawat atau dengan guru dalam upaya mengembangkan pengetahuan siswa yang menyebabkan siswa menjadi pasif dan sulit untuk memahami dan menguasai materi pelajaran, sehingga aktifitas dan hasil belajar kurang maksimal.

Salah satu upaya yang dapat dilakukan untuk mengatasi permasalahan di atas adalah dengan menerapkan model pembelajaran agar seluruh siswa lebih aktif dalam proses pembelajaran. Salah satu model yang ditawarkan oleh peneliti adalah model pembelajaran berbasis masalah. Arends (2012) menyatakan bahwa model pembelajaran berbasis masalah merupakan suatu pendekatan pembelajaran dimana siswa mengerjakan permasalahan yang autentik dengan maksud untuk menyusun pengetahuan mereka sendiri, mengembangkan inkuiri dan keterampilan berpikir tingkat lebih tinggi, mengembangkan kemandirian dan percaya diri.

Selain Arends, Trianto (2010) berpendapat bahwa model pembelajaran berbasis masalah merupakan pendekatan yang efektif untuk pengajaran proses berpikir tingkat tinggi. Selain itu, Sanjaya (2011) juga menyatakan bahwa model pembelajaran berbasis masalah adalah rangkaian aktivitas pembelajaran yang menekankan kepada proses penyelesaian masalah yang dihadapi secara ilmiah.

Model pembelajaran berbasis masalah ini memiliki kelebihan yaitu mengarahkan dan menolong siswa dalam menanamkan pengetahuan baru melalui penyajian masalahmasalah yang memerlukan tingkat berpikir yang tinggi. Masalah yang disajikan berkaitan dengan pengalaman dalam kehidupan seharihari, sehingga lebih mudah untuk dinalar. Melalui masalah-masalah yang disajikan, model probem based learning juga dapat membantu siswa mengingat dan mengaitkan kembali pengetahuan lama dengan materi yang baru dipelajari sehingga dapat ditemukan konsep yang sebenarnya.

Berdasarkan permasalahan di atas, maka peneliti berkeinginan untuk melakukan penelitian dengan tujuan untuk melihat pengaruh model pembelajaran berbasis masalah terhadap hasil belajar siswa pada materi Listrik Dinamis di kelas X semester II SMA Negeri 14 Medan T.P 2014/2015".

\section{METODE PENELITIAN}

Penelitian ini termasuk quasi experiment. Penelitian ini dilaksanakan di SMA Negeri 14 Medan yang beralamat Jln.Pelajar Timur Ujung Gg. Darmo Kec.Medan Timur. Waktu penelitian dilakukan Semester II T.P.2014 / 2015.

Populasi dalam penelitian ini adalah seluruh kelas X Semester II SMA Negeri 14 Medan yang terdiri dari 9 kelas. Sampel dalam penelitian ini terdiri dari dua kelas yaitu kelas X-3 sebayak 35 orang sebagai kelas 
eksperimen dan kelas X-2 sebanyak 36 orang sebagai kelas kontrol yang diambil dengan teknik cluster random sampling.

Instrumen yang digunakan adalah tes hasil belajar siswa dan lember observasi aktivitas siswa. Tes hasil belajar berjumlah 15 soal dalam bentuk pilihan berganda dengan lima pilihan (option) yang terlebih dahulu sudah di validasi isi oleh para ahli. Tes ini diberikan sebanyak 2 kali yaitu pada saat pretes dan postes. Lembar observasi digunakan untuk mengamati aktivitas belajar siswa selama pelaksanaan pembelajaran. Observasi dilakukan oleh observer yang berjumlah dua orang.

Penelitian ini melibatkan dua kelas yang diberi perlakuan yang berbeda. Untuk mengetahui hasil belajar fisika siswa dilakukan dengan memberikan tes pada kedua kelas sebelum dan sesudah diberikan perlakuan. Desain penelitian dapat dilihat pada Tabel 1.

Tabel.1 Two Group Pretest dan Postest

\begin{tabular}{|l|l|l|l|}
\hline Kelas & $\begin{array}{l}\text { Pre } \\
\text { Tes }\end{array}$ & Perlakuan & $\begin{array}{l}\text { Pos } \\
\text { Tes }\end{array}$ \\
\hline Eksperimen & $\mathrm{T}_{1}$ & $\mathrm{X}$ & $\mathrm{T}_{2}$ \\
\hline Kontrol & $\mathrm{T}_{1}$ & $\mathrm{Y}$ & $\mathrm{T}_{2}$ \\
\hline
\end{tabular}

Keterangan :

T1 : Tes kemampuan awal (pretes) untuk kelas eksperimen dan kelas kontrol.

T2 : Tes kemampuan akhir (postes) untuk kelas eksperimen dan kelas kontrol.

X1 : Perlakuan pembelajaran dengan model pembelajaran berbasis masalah

Y : Perlakuan pembelajaran dengan model pembelajaran konvensional.

Hasil pretes yang diperoleh dilakukan uji prasyarat yaitu uji normalitas untuk mengetahui apakah data berdistribusi normal atau tidak. Kemudian dilakukan uji homogen untuk mengetahui apakah data bersifat homogen atau tidak. Setelah data berdistribusi normal dan juga homogen, maka dilakukan Uji t dua pihak (uji kemampuan awal/pretes) yang digunakan untuk mengetahui kesamaan kemampuan awal siswa pada kedua kelompok sampel. (Sudjana, 2005). Selanjutnya apabila kedua kelas sampel diketahui mempunyai kemampuan awal yang sama maka kedua sampel diberikan perlakuan yang berbeda. Kelas eksperimen diberikan perlakuan dengan model pembelajaran berbasis masalah dan kelas kontrol diberikan perlakuan dengan menggunaka model pembelajaran konvensional. Setelah diberikan perlakuan maka selanjutnya adalah kedua kelas diberikan postes. Untuk mengolah data pada postes sama seperti pada pretes dilakukan uji prasyarat yaitu uji normalitas dan uji homogen. Setelah data berdistribusi normal dan juga homogen maka dilakukaan uji t (uji kemampuan akhir/postes) yang digunakan untuk mengetahui apakah hasil belajar siswa dengan menerapkan model pembelajaran berbasis masalah lebih baik dibandingkan dengan model pembelajaran konvensional pada materi pokok listrik dinamis.

\section{HASIL DAN PEMBAHASAN Hasil Penelitian}

Adapun hasil penelitian ini adalah bahwa nilai rata-rata pretest kelas eksperimen sebesar 35,74 dan nilai rata-rata kelas kontrol sebesar 36,75. Data pretes berdistribusi normal dan homogen, maka dilakukan uji hipotesis data pretes menggunakan uji t. 
Berdasarkan hasil perhitungan uji $t$, maka disimpulkan bahwa siswa kelas eksperimen dengan siswa kelas kontrol mempunyai kemampuan awal yang sama. Hasil pretes siswa digambarkan pada Tabel 2 .

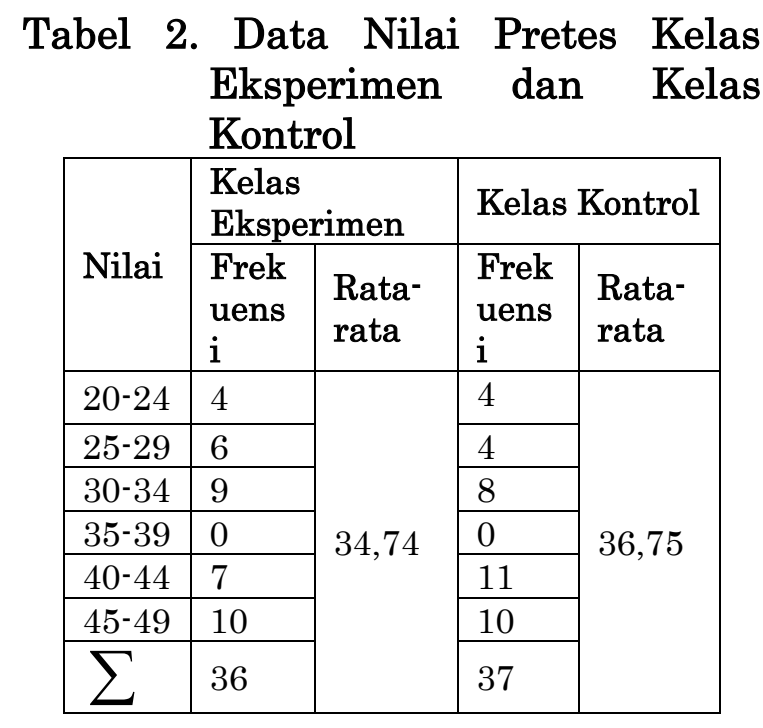

Setelah diberikan perlakuan yang berbeda,diperoleh bahwa ratarata post-test kelas eksperimen sebesar 74,04 dan rata-rata post-test kelas kontrol sebesar 68,47. Data postes berdistribusi normal dan homogen, maka dilakukan uji hipotesis data postes menggunakan uji t. Hasil pretes siswa digambarkan pada Tabel 3.

Tabel 3. Data Nilai Postes Kelas Eksperimen dan Kelas Kontrol

\begin{tabular}{|c|c|c|c|c|}
\hline \multirow[b]{2}{*}{ Nilai } & \multicolumn{2}{|c|}{$\begin{array}{l}\text { Kelas } \\
\text { Eksperimen }\end{array}$} & \multicolumn{2}{|c|}{$\begin{array}{l}\text { Kelas } \\
\text { Kontrol }\end{array}$} \\
\hline & $\begin{array}{l}\text { Frek } \\
\text { uens } \\
\mathrm{i}\end{array}$ & $\begin{array}{l}\text { Rata- } \\
\text { rata }\end{array}$ & $\begin{array}{l}\text { Frek } \\
\text { uens } \\
\text { i }\end{array}$ & $\begin{array}{l}\text { Rata- } \\
\text { rata }\end{array}$ \\
\hline $20-24$ & 4 & \multirow{7}{*}{34,74} & 4 & \multirow{7}{*}{36,75} \\
\hline $25-29$ & 6 & & 4 & \\
\hline $30-34$ & 9 & & 8 & \\
\hline $35-39$ & 0 & & 0 & \\
\hline $40-44$ & 7 & & 11 & \\
\hline $45-49$ & 10 & & 10 & \\
\hline$\sum$ & 36 & & 37 & \\
\hline
\end{tabular}

Perkembangan aktivitas belajar siswa pada kelas eksperimen dankelas kontrol diamati selama tiga kali pertemuan dan hasil perkembangan aktivitas siswa dapat dilihat pada Gambar 1.

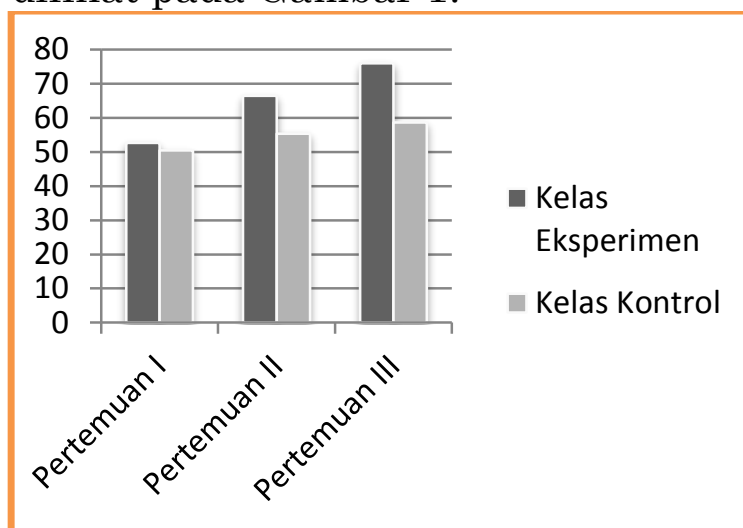

\section{Gambar 1. Diagram Batang Perkembangan \\ Aktivitas Siswa}

\section{Pembahasan}

Hasil penelitian menunjukkan bahwa ada pengaruh penggunaan model pembelajaran berbasis masalah terhadap hasil belajar siswa pada materi pokok Listrik Dinamis. Hal ini dibuktikan dengan nilai ratarata post-test kelas eksperimen adalah 74,07 sedangkan nilai ratarata postes kelas kontrol adalah 68,29 . Adanya peningkatan aktivitas pada kelas eksperimen yaitu pertemuan I 52,63\% atau tidak aktif, pertemuan II $66,52 \%$ atau cukup aktif dan pertemuan III 76,04\% atau aktif, sedangkan aktivitas di kelas kontrol yaitu pertemuan I 50,45\% atau tidak aktif, pertemuan II $55,41 \%$ atau kurang aktif dan pertemuan III 58,67\% atau kurang aktif, hal ini di dapat karena model pembelajaran berbasis masalah yang digunakan dapat mengarahkan siswa untuk terlibat secara aktif dalam pembelajaran. Siswa dituntut untuk aktif baik dari segi individual maupun berkelompok. 
Tahap orientasi siswa pada masalah, peneliti mengajukan suatu permasalahan yang dikaitkan dengan pelajaran untuk dikerjakan oleh siswa secara pribadi, dan siswa berpikir secara mandiri mengenai permasalahan yang diajukan. Pada tahapan ini, siswa berusaha untuk memperoleh jawaban sendiri sesuai dengan kemampuan masing-masing. Siswa di ajak aktif untuk berpikir mengenai permasalahan yang diberikan oleh peneliti. Siswa membayangkan, mengingat dan mencari beberapa alasan yang berkaitan dengan masalah tersebut, sehingga pada tahap ini siswa kelihatan aktif, tertarik dan termotivasi untuk masuk ke tahap berikutnya.

Tahap mengorganisasi siswa untuk belajar, siswa duduk berkelompok dengan teman satu kelompok yang telah ditentukan sebelumnya, siswa melakukan interaksi mengenai apa yang di bahas di fase sebelumnya. Interaksi selama tahap ini sesama anggota kelompok dapat memadukan jawaban tentang permasalahan yang diberikan oleh peneliti sebelumnya, siswa saling tukar pikiran untuk mendapatkan solusi, jawaban tentang permasalahan yang diberikan peneliti. Dengan adanya diskusi dalam kelompok, masing-masing siswa terlihat aktif, saling bekerja sama.

Tahap penyelidikan kelompok peneliti memberikan fasilitas berupa Lembar Kerja Siswa (LKS), alat dan bahan. Dengan dan fasilitas ini, masing-masing siswa dalam kelompok berusaha memecahkan masalah yang diberikan oleh peneliti. Pada fase ini, masing-masing siswa terlihat lebih aktif dan memiliki rasa ingin tahu tentang apan yang akan dilakukan selanjutnya. Kebersamaan dalam kelompok masing-masing sudah terlihat, ada yang penasaran tentang alat dan bahan yang diberikan, sesama anggota kelompok saling bertanya akan kegunaan alat dan bahan yang diberikan dan mereka ingin sekali menggunakan alat tersebut. Pada fase ini peneliti membimbing siswa untuk melakukan percobaan, tapi sebelum percobaan dilakukan, peneliti terlebih dahulu menjelaskan bagaimana cara menggunakan alat dan bahan yang telah disediakan. Setelah itu, siswa antusias melakukan percobaan sesuai dengan LKS yang diberikan oleh peneliti. Selama percobaan, siswa kelihatan kompak, aktif, dan bekerja sama dengan teman kelompoknya masing-masing. Pada tahap ini, siswa mulai mengetahui tentang permasalahan yang diberikan sebelumnya, setiap kelompok memecahkan masalah yang diberikan peneliti sebelumnya dan menuliskan hasil yangdi dapat di LKS yang telah diberikan. Selama proses ini, observer mengamati setiap kelompok untuk mengetahui aktivitas masingmasing siswa.

Tahap menyajikan hasil karya, peneliti menunjuk beberapa kelompok untuk mempresentasikan hasil diskusi kelompoknya. Waktu ada kelompok yang maju untuk mempresentasikan hasil diskusinya, kelompok lain menyimak dan memperhatikan apa yang dibacakan oleh kelompok yang presentasi. Di sini, masing-masing siswa lebih memahami dan bertanya kepada sesama kelompok, dan saling memberikan masukan. Dengan presentase tersebut, kelompok lainnya dapat membandingkan hasil 
yang diperolehnya sehingga meningkatkan pemahaman siswa terhadap materi yang sedang dipelajari.

Tahap menganalisis dan mengevaluasi proses pemecahan masalah, siswa menanyakan bagian mana yang kurang dipahami baik pada kelompok yang presentase atau pun kepada peneliti.

Kelas eksperimen banyak mengalami perubahan tingkah laku selama pembelajaran. Hal ini disebabkan karena siswa kelas eksperimen memperoleh pengetahuannya dari berbagai sumber, yaitu saat mereka merumuskan hipotesis, mereka dapat mengajukan pemikiran awalnya tentang permasalahan yang disajikan pada pembelajaran tersebut. Selain itu, sumber pengetahuan lainnya adalah dengan melakukan percobaan untuk memeriksa kebenaran dari hipotesis yang telah mereka ajukan sebelumnya, sehingga mereka dapat membuat kesimpulan berdasarkan hipotesis, percobaan dan teori sebenarnya.

Berdasarkan uraian diatas dapat disimpulkan bahwa model pembelajaran berbasis masalah dapat meningkatkan keterampilan siswa dan rasa percaya diri siswa. Hal ini didukung oleh Arends (2012) yang menyatakan bahwa pembelajaran berdasarkan masalah merupakan suatu pendekatan pembelajaran di mana siswa mengerjakan permasalahan yang autentik dengan maksud untuk menyusun pengetahuan mereka sendiri, mengembangkan inkuiri dan keterampilan berpikir tingkat lebih tinggi, mengembangkan kemandirian dan percaya diri.

Berdasarkan hasil penelitian terdahulu yang dilakukan oleh Selcuk
(2010) menyatakan bahwa mengajar ilmu fisika menggunakan model problem based learning jauh lebih efektif keberhasilannya daripada menggunakan pembelajaran konvensional. Selain itu, model problem based learning juga dapat meningkatkan hasil belajar secara berkelompok bukan hanya secara individu. Pembelajaran berdasarkan masalah merupakan teknik yang cukup bagus untuk lebih memahami isi pelajaran dan membantu siswa bagaimana mentransfer pengetahuan mereka untuk memahami masalah dalam kehidupan nyata.

Model problem based learning juga dapat meningkatan aktivitas belajar dan berpikir kreatif siswa. Berdasarkan hasil peneliti terdahulu, Saputra, dkk (2012) menyatakan bahwa terdapat peningkatan yang signifikan terhadap keterampilan berpikir kreatif siswa setelah diterapkan model problem based learning menggunakan praktikum alat sederhana. Hal ini disebabkan karena model problem based learning dengan menggunakan praktikum alat sederhana mengharuskan siswa aktif dan membiasakan untuk berpikir kreatif, Pernyataan ini telah dibuktikan oleh peneliti saat melakukan penelitian di SMA Negeri 14 Medan.

Selama penelitian ini ditemukan beberapa kendala yang dialami oleh peneliti pada saat menggunakan model pembelajaran antara lain adalah: (1) situasi yang kurang kondusif pada saat pembelajaran di mana pada tahap mengorganisasikan siswa untuk belajar ada sebagian siswa yang tidak membahas tentang permasalahan yang diberikan justru membahas hal lain di luar permasalahan yang diberikan 
sehingga siswa tersebut kurang memahami maksud dari masalah yang diberikan. Hal ini mengganggu suasana pembelajaran di kelas karena siswa lain tidak nyaman dalam belajar. Selain itu kendala tersebut sangat berpengaruh pada tahap berikutnya karena pemahaman siswa pada tahap mengorganisasikan siswa untuk belajar mempengaruhi efektivitas pembelajaran pada tahap penyelidikan kelompok. (2) Pada saat melakukan percobaan ada sebagian siswa yang kurang terlibat, ada yang hanya menunggu hasil, duduk dan hanya melihat saja, sementara teman kelompoknya sibuk. Beberapa kelompok mengalami kesulitan dalam pelaksanaan kegiatannya, hal ini mengakibatkan aktivitasnya agak lambat berkembang dibanding dengan kelompok lain. Hal ini kemungkinan disebabkan karena pembagian kelompok yang kurang diperhatikan keadaan anggota masing-masing kelompok. Untuk meningkatkan kekompakan anggota kelompok perlu dilakukan pengelompokan secara acak, misalkan laki-laki di gabung dengan perempuan, yang ribut dengan yang diam, yang pintar dengan yang kurang pintar, supaya bisa saling membantu satu sama lain, dan kelompok tidak mendominasi, akan tetapi bisa saling melengkapi (3) kurangnya komunikasi antara peneliti dan observer di mana tidak semua siswa yang dipantau oleh observer diketahui keadaannya oleh peneliti, sehingga peneliti tidak melakukan perlakuan tersendiri kepada beberapa siswa untuk meningkatkan hasil belajarnya. Komunikasi antara observer dan peneliti sangat dibutuhkan untuk meningkatkan hasil belajar siswa.

\section{KESIMPULAN DAN SARAN Kesimpulan}

Berdasarkan hasil analisis data, dapat disimpulkan bahwa ada pengaruh penggunaan model pembelajaran berbasis masalah untuk terhadap hasil belajar siswa pada materi listrik dinamis kelas X.

\section{Saran}

Berdasarkan hasil pembahasan penelitian yang dikemukakan maka untuk tindak lanjut penelitian ini, peneliti mempunyai beberapa saran diantaranya adalah kepada peneliti selanjutnya diharapkan agar lebih maksimal dalam membimbing siswa pada setiap tahap terutama pada tahap mengorganisasikan siswa untuk belajar, kepada peneliti selanjutnya diharapkan agar memperhatikan keadaan siswa dalam pembentukan kelompok dan kepada peneliti selanjutnya diharapkan berkomunikasi lebih baik dengan observer tentang kondisi siswa.

\section{DAFTAR PUSTAKA}

Arends, R., (2012), Learning To Teach, Penerbit Pustaka Pelajar, Yogyakarta.

Sagala, S., (2009), Konsep dan Makna Pembelajaran,

Alfabeta, Bandung.

Saputra, dkk,. (2012), Pengaruh Menggunakan Praktikum Alat Sederhana Terhadap Keterampilan Berpikir Kreatif Siswa SMA Negeri 7 Palu, Jurnal Pendidikan Fisika Tadulako Vol. 2 No.2

Selcuk, G. S., (2010), The effects of problem-based learning on preservice teachers' achievement, 
approaches and attitudes towards learning physics, International Journal of the Physical Sciences Vol. 5(6), pp. 711-723

Sudjana, (2005), Metoda Statistika. Penerbit Tarsito, Bandung.

Trianto., (2010), Mendesain Model Pembelajaran InovatifProgresif, Kencana Prenada Media Group, Jakarta. 